\section{The peculiar health beliefs of the Nacirema}

\author{
John Launer
}

In 1956, the American anthropologist Horace Miner published a seminal paper describing the peculiar health beliefs and practices of a tribe known as the Nacirema. 'While much of the people's time is devoted to economic pursuits' he wrote, 'a large part of the fruits of these labours and a considerable portion of the day are spent in ritual activity. The focus of this activity is the human body, the appearance and health of which loom as a dominant concern in the ethos of the people.' He went on to describe the tribe's fundamental belief that the human body is ugly and has a natural tendency to debility and disease. The only hope of averting this lay in ritual and ceremony. Because of this, Miner explained, every Nacirema house has one or more shrines, where the focal point is a box or chest built into the wall, containing 'charms and magic potions without which no native believes he can live.' These have all been prescribed by medicine men who write them down in a secret language for a fee. The medicine men dwell in what they call a latipso with a permanent group of vestal maidens who move sedately around the temple chambers in a distinctive costume and headdress. For supplicants who enter there, the latipso ceremonies are harsh, involving discomfort and torture. 'The ritual life of the Nacirema' Miner concluded, has shown them to be a magic-ridden people. It is hard to understand how they have managed to exist so long under the burdens which they have imposed on themselves.'

Miner's description of the Nacirema is so bizarre and so shocking that it is well worth reading in its entirety, especially the paragraphs relating to the sadistic tooth operations of the 'holy mouth-men,' the expensive exorcisms carried out by 'listeners' to whom bewitched members of the tribe tell their life stories, the women's general dissatisfaction with their breast shape and size, and the secrecy surrounding sex and childbirth. The account is also

Correspondence to Dr John Launer, Associate Editor, Postgraduate Medical Journal, Health Education England, London WC1B 5DN, UK; johnlauner@aol.com totally hilarious. Miner gives the game away early on in the article by telling readers that the Nacirema inhabit the territory between the Canadian Cree and the Yaqui of Mexico. He is of course describing the Americans (try reading Nacirema backwards if you haven't already) and their obsession with medical and dental treatment, and with their hospitals.

\section{FLIGHT OF FANCY}

Miner's delightful flight of fancy has been used a great deal to help social science students to learn - among other things how to take a detached view of the people and groups they study, as well as a sceptical position in relation to their own perspectives and assumptions. ${ }^{2}$ It has also given rise to other spoofs, including a much longer but rather plodding account of the Nacirema legal system. ${ }^{3}$ However, by far the most powerful adjunct to Miner's fantasy was written by Marie Scott Brown, a nurse anthropologist from Oregon, who elaborated on the maternal and child care practices of the Nacirema ${ }^{4}$ Her account of birth within the tribe is as follows:

When the time of delivery is near, the Vestal Virgins position the woman in one of the most torturous of the culture's institutions, a special apparatus used only at the time of birth. In it the woman is made to lie flat on her back with her legs and feet raised at a 90 degree angle and bent at the knee. It is thought that if a woman is able to deliver her baby in this almost impossible position, she will have passed the first initiation rites of motherhood.

Elsewhere, Brown points out the sharp division in the latipsos between the erac treatments provided by the vestal maidens, and the eruc ones that are exclusive to the medicine men. ${ }^{5}$ She then describes how these different categories of treatment are often delivered to the same person in isolation from each other. Brown identifies other powerful professions and institutions, including locias srekrows who look after delinquent young people, and the loohcs where children are taught senseless competitive games.

Altogether, Brown's article is far more lacerating than Miner's. It amounts to a Swiftian satire of how childcare practices in the United States enact multiple cruelties in the name of materialism. She also makes unfavourable comparisons with the state-supported and extended family care for children that she has seen elsewhere:

Perhaps even more than had been the case with the trip to the Soviet Union, China and Africa, our visit with the Naciremans had exposed us to patterns of health and illness and a healthcare system so unusual that we felt it must demonstrate the true plasticity of human nature. That a culture and healthcare system so incomprehensible could persist over the years and maintain a viable country was indeed a tribute to the real strength of human nature. ${ }^{5}$

\section{CRITICAL THOUGHT}

So far as I am aware, the articles by Miner and Brown have never entered the medical school curriculum. They also appear to be quite unknown to medical educators. This is a pity. I suggest that they could be employed to promote observation, critical thought, and a broader political perspective on the assumed cultural 'normalities' of medicine, just as they are used in university departments of anthropology and sociology. Although written many decades ago, they relate more than ever to some of the current preoccupations of medicine - including overdiagnosis, overtreatment, health obsessions, and body dysmorphia. They also point to the inescapable connection between these growing problems and the massive role of big business in persuading people to spend more and more of the 'fruits of their labours' in 'ritual activity' to stave off ugliness, debility and disease. Most of all, Miner and Brown draw attention to these issues with stylish humour (gently mocking in the former case, savage in the latter) that is often the best way of framing any critique of irrational but pervasive systems of belief - and that might enable us as a profession to challenge our own more effectively. I can think of no better way to promote a discussion of how to help ourselves and our patients become liberated from our enslavement to the uncritical rituals of latipsos, erac and eruc.

Funding The authors have not declared a specific grant for this research from any funding agency in the public, commercial or not-for-profit sectors.

Competing interests None declared.

Patient consent Not required.

Provenance and peer review Not commissioned; internally peer reviewed.

(C) Author(s) (or their employer(s)) 2018. No commercial re-use. See rights and permissions. Published by BMJ. 


\section{D) Check for updates}

To cite Launer J. Postgrad Med J 2018;94:423-424.

Postgrad Med J 2018;94:423-424.

doi:10.1136/postgradmedj-2018-135921

\section{REFERENCES}

1 Miner H. Body Ritual among the Nacirema. Am Anthropol 1956;58:503-7.

2 Burde M. Social-Science Fiction: The Genesis and Legacy of Horace Miner's "Body Ritual among the Nacirema". Am Anthropol 2014;104:549-61.
3 Dimsdale JE. The Nacirema revisited. Ann Behav Med 2001:23:75-6.

4 Brown MS. Culture and childrearing. In: Clark AL, ed. Culture and childrearing. Philadelphia, PA: FA Davis Company, 1981:2-35.

5 Brown MS. Maternal-child care in Nacirema. Image J Nurs Sch 1986;18:74-7. 